\title{
The cell population of the upper jejunal mucosa in tropical sprue and postinfective malabsorption
}

\author{
R. D. MONTGOMERY AND A. C. I. SHEARER \\ From the Metabolic Unit, East Birmingham Hospital, Birmingham
}

SUMMARY The cell population of the upper jejunal mucosa has been studied in cases of tropical sprue from the Far East and Middle East, and in similar cases arising in western Europe ("postinfective malabsorption'), and compared with cases of untreated coeliac disease and patients without small bowel disease.

Infiltration of the epithelial layer of the upper jejunal mucosa by lymphocytes was found in tropical sprue to the same extent as in coeliac disease, and, to a lesser extent, in 'postinfective malabsorption'.

In the lamina propria, in all forms of acute sprue there was an increased density of lymphocytes. With increasing duration and with increasing mucosal atrophy, the lymphocytes were progressively replaced by plasma cells, and the cellular infiltration in chronic sprue was indistinguishable from that of coeliac disease.

The findings suggest that a humoral antibody response is a feature of sprue, and becomes more prominent as the condition becomes chronic.

In the upper jejunal mucosa in cases of coeliac disease there is an excessive lymphocytic infiltration of the epithelium (Ferguson and Murray, 1971) whereas in the lamina propria the concentration of lymphocytes is reduced but there is an excess of plasma cells (Holmes, Asquith, Stokes, and Cooke, 1973).

-In tropical sprue, hypercellularity of the lamina propria has often been described, and reference was made by Thurlbeck, Benson, and Dudley (1960), by Chacko, Job, Johnson, and Baker (1961), and by England and O'Brien (1966) to an apparent excess of lymphocytes in the epithelium, but cell counts have not been reported.

We have studied the lymphocyte and plasma cell population in jejunal biopsy specimens in cases of tropical sprue and compared them with cases of 'postinfective malabsorption' acquired in western Europe, and with cases of untreated adult coeliac disease.

\section{Materials and Methods}

Eight of the jejunal biopsy specimens were from patients with tropical sprue acquired in South-East Asia. Four of these were young British servicemen Received for publication 15 March 1974. repatriated from Hong Kong and Malaya with acute sprue; three others were cases of more than a year's duration acquired in India (two Indian immigrants and one English traveller), and one was a case of longstanding disease from China. Four cases were of a sprue syndrome arising in the Middle East and indistinguishable from tropical sprue (Haeney, Montgomery, and Schneider, 1974) (three British expatriates with an acute illness and one Yemenite with 18 months' history). Nine cases were of a similar acute illness described as postinfective malabsorption and acquired in western Europe (Montgomery, Beale, Sammons, and Schneider, 1973).

The 12 cases of coeliac disease were untreated adults in whom gluten sensitivity was subsequently confirmed. As controls, biopsies were studied from 20 patients who presented with abdominal symptoms or anaemia, but in whom detailed investigations showed no evidence of small-bowel disease.

Biopsies were taken under radiological control from the upper jejunum. The cut sections were of $5 \mu$ thickness. Lymphocytes in the epithelium were counted per 100 epithelial cells from four different well orientated areas of each specimen, and the mean of the four counts was taken.

Lamina propria counts were made per unit 
area, using oil immersion and a graticule. Separate counts were made (a) at the level of the base of the crypts ('deep' counts) and (b) in the middle of the villi where these were well formed, or beneath the epithelium near the luminal surface in atrophic specimens ('superficial' counts).

In each instance four counts were made from different areas, and the mean was expressed as cells per sq $\mathrm{mm}$. A variety of stains was employed, but for the simultaneous counting of lymphocytes and plasma cells, standard lightly stained haematoxylineosin sections were found to be satisfactory.

\section{Results}

\section{INTEREPITHELIAL LYMPHOCYTES}

In 20 normal subjects the range of lymphocyte counts within the epithelial layer was 7-22 per 100 epithelial cells.

In postinfective malabsorption there was a slight rise above this range (fig 1). In tropical sprue the counts were invariably raised, up to 96 per 100 epithelial cells.

The duration of illness in postinfective cases at the time of biopsy was from six to 11 weeks, whereas the duration was longer than 10 weeks in all the tropical sprue cases. The three highest counts (over 80 per 100 cells) were in cases with over six months' history. Apart from this, the interepithelial lympho-

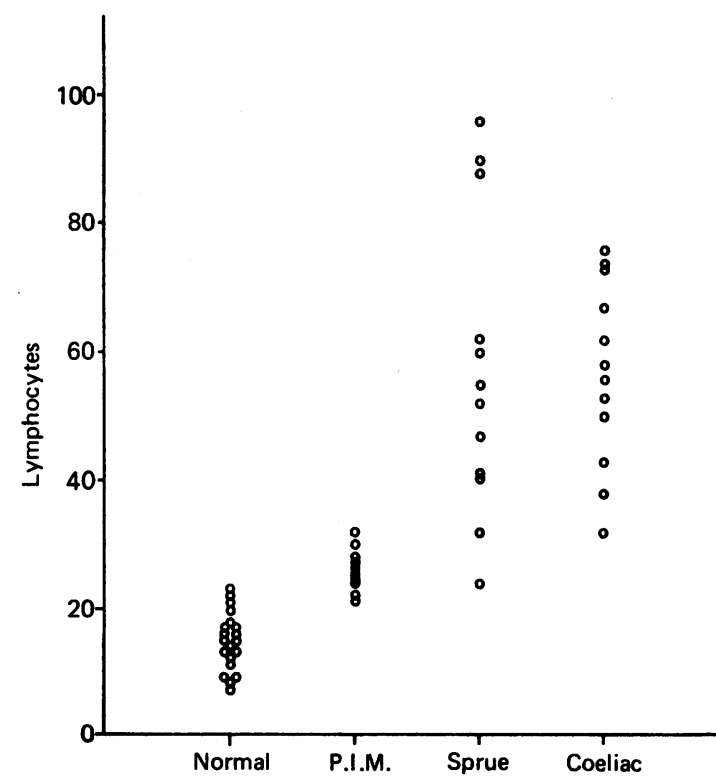

Fig 1 Interepithelial lymphocyte counts in all specimens (lymphocytes per 100 epithelial cells). cyte counts bore no constant relation to the length of history within the sprue series.

In coeliac disease the counts ranged from 32 to 76, with a mean of 57 per 100 epithelial cells.

\section{THE LAMINA PROPRIA}

In normal subjects, the cell population of the lamina propria increased progressively from the tip to the base of the villi (table I). This applied particularly to the plasma cells which were scanty and variable at the tips, and ranged from 341 to 2060 per sq $\mathrm{mm}$ at the level of the crypts. Small numbers of eosinophils featured in the counts of only five normal subjects; they tended to occur in small clumps in the villi.

In postinfective malabsorption there was an

\begin{tabular}{lccc}
\hline & Tip of Villus & Mid Villus & Base of Crypts \\
\hline Plasma cells & 335 & 708 & 1117 \\
Lymphocytes & 1963 & 2606 & 3482 \\
Other cells & 4547 & 5083 & 6422 \\
Total cells & 6845 & 8397 & 11021 \\
\hline
\end{tabular}

Table I Cell densities in the normal lamina propria in the villi and at the level of the base of the crypts ${ }^{1}$

${ }^{1}$ Mean counts per sq $\mathbf{~ m m}$ in 20 specimens.

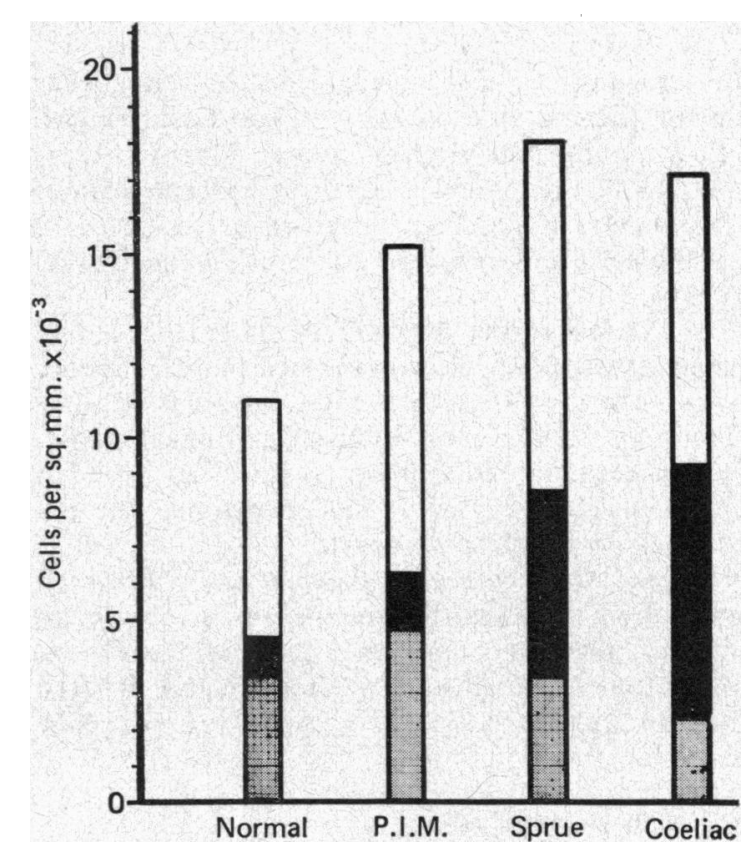

Fig 2 Densities of lymphocytes, plasma cells, and other cells in the lamina propria. The figures given are the mean of deep and superficial counts (see text), in each diagnostic group. II lymphocytes, $\square$ plasma cells, $\square$ other cells. 


\begin{tabular}{llll}
\hline & Total Cells (Mean \pm SEM) & Lymphocytes (Mean \pm SEM) & $\begin{array}{l}\text { Plasma Cells } \\
\text { (Mean } \pm \text { SEM) }\end{array}$ \\
\hline $\begin{array}{l}\text { Normal } \\
\text { (range) }\end{array}$ & $11021 \pm 604$ & $3482 \pm 442$ & $1117 \pm 113$ \\
$\begin{array}{c}\text { Postinfective malabsorption } \\
\text { (range) }\end{array}$ & $(5853-17201)$ & $(1203-9979)$ & $(341-2060)$ \\
$\begin{array}{c}\text { Tropical sprue } \\
\text { (range) }\end{array}$ & $15155 \pm 729$ & $6057 \pm 958$ & $1470 \pm 226$ \\
$\begin{array}{c}\text { Coeliac disease } \\
\text { (range) }\end{array}$ & $(12220-20123)$ & $(2406-13074)$ & $(519-2742)$ \\
& $(9657 \pm 1298$ & $3741 \pm 703$ & $3852 \pm 833$ \\
\end{tabular}

Table II Cell densities in the lamina propria ('deep counts') in normal subjects, postinfective malabsorption, tropical sprue, and untreated coeliac disease ${ }^{1}$

${ }^{2}$ Mean counts per sq $\mathrm{mm}$ area \pm standard error of mean (SEM)

increase in lymphocytes and to a lesser extent in plasma cells at all levels (fig 2). In tropical sprue also there tended to be an increase in lymphocytes, but at the base of the crypts the mean figure for the series was not significantly above normal; the plasma cell counts were significantly high (table II).

In coeliac disease, as shown in fig 2 , the plasma cell count reached even higher levels, whereas the lymphocytes were slightly reduced.

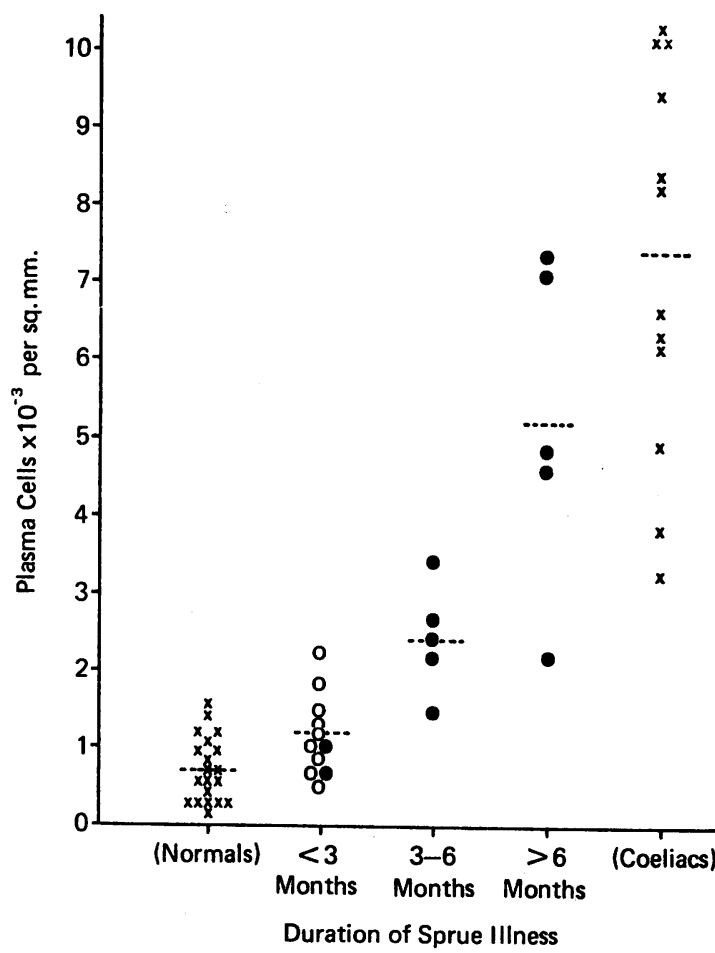

Fig 3 Density of plasma cells in the lamina propria in cases of the sprue syndrome, related to the duration of illness. White circles represent cases of postinfective malabsorption (PIM) and black circles represent cases of tropical sprue. The mean figures are also shown.
The eosinophil counts in postinfective malabsorption and coeliac disease did not differ from normal. In tropical sprue the mean count was slightly raised, these cells being observed in small numbers in seven out of 12 cases.

Analysis of cell counts in relation to the duration of disease showed that with increasing chronicity there was a progressive increase in the plasma cell density (fig 3). The lymphocyte counts were more variable but tended to fall from their initial high level, particularly after six months (table III).

\begin{tabular}{llll}
\hline & $\begin{array}{l}\text { Less than Three } \\
\text { Months }\end{array}$ & Three-Six Months & Over Six Months \\
\hline Mean & 5785 & 5160 & 2875 \\
SEM & 876 & 2344 & 811 \\
Range & $2752-13070$ & $1720-9632$ & $688-7052$
\end{tabular}

Table III Density of lymphocytes in lamina propria

in cases of sprue related to duration of illness ${ }^{\mathrm{l}}$

${ }^{1}$ Mean counts per sq $\mathbf{m m}$ and standard error of mean (SEM)

The plasma cell count showed a correlation with the degree of villous atrophy (fig 4). Atrophy was greater in the coeliac patients, nine of whom had a flat or 'mosaic' mucosa, with subtotal atrophy.

No significant changes were detected among other cell types in the lamina propria, which included fibroblasts, histiocytes, capillary endothelium, and small numbers of neutrophils and mast cells.

\section{Discussion}

The interepithelial lymphocyte counts in our normal subjects are lower by some $30 \%$ than the normal range established in 40 cases by Ferguson and Murray (1971), and our figures for coeliac disease also are correspondingly lower than theirs. We believe that this may be due to the fact that our sections were $5 \mu$ in thickness compared with $7 \mu$. Lymphocytes stand out more clearly than the epithelial cells, and the numbers of the latter tend to be 


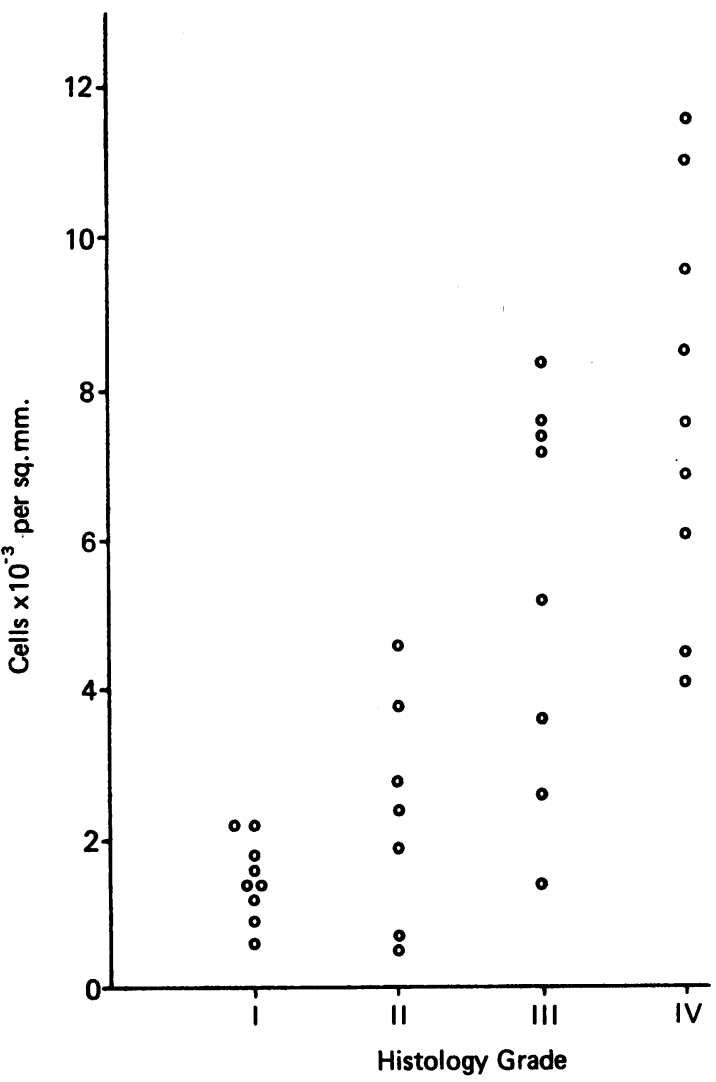

Fig 4 Density of plasma cells in the lamina propria in cases of the sprue syndrome related to morphological changes. Grade I = normal; $I I=$ mild partial atrophy; III = moderate or severe partial atrophy; $I V=$ subtotal atrophy (Whitehead, 1971).

underestimated in thicker sections, in which constant refocusing is required.

We have shown that the epithelial lymphocytes are slightly increased in cases of postinfective malabsorption arising in Europe, and markedly increased in tropical sprue, particularly in chronic cases. The range in tropical sprue is similar to that of coeliac disease.

Like Ferguson and Murray (1971), we have found other conditions in which the count is increased. One of the highest counts was in a patient who had repeated attacks of dysentery during an overland journey to India-requiring a short spell in hospital in India with intravenous therapy. At the time of biopsy after her return she had mild abdominal symptoms, but tests showed no evidence of malabsorption. The lymphocyte count was 90 per 100 epithelial cells; in all other respects the jejunal morphology was normal.
We have also found raised counts in a case of Whipple's disease before treatment, in two cases of hypogammaglobulinaemia with malabsorption, and in a few but not all cases of the blind-loop syndrome due to small bowel diverticulosis. In all these conditions the upper jejunal mucosa may possibly be exposed to an unusual bacterial challenge. On the other hand, it can hardly be claimed that this is a specific response either to bacteria or gluten. Thompson (1973) has found increased interepithelial lymphocyte counts in the duodenal bulb in chronic duodenitis, and Ferguson and Murray (1971) reported high counts in generalized autoimmune disorders.

With regard to the lamina propria, we have confirmed earlier observations that the density of lymphocytes and plasma cells tends to be increased in tropical sprue. Rubin and Dobbins (1965) observed that the predominant cells of the lamina propria were lymphocytes in tropical sprue, as compared with plasma cells in coeliac disease. Our individual counts, however, show that the process is a dynamic one. With evolution of the sprue illness, the initially high lymphocyte population is progressively replaced by plasma cells, which come to dominate the picture in chronic cases, just as they do in coeliac disease.

As a rule the highest plasma cell counts were found in the flattest biopsies. There was a broad overlap between sprue and coeliac cases, and in biopsies with a comparable degree of partial atrophy there was no numerical difference in the cell populations. Nor could we find any other features specific for either condition. Abnormal morphology of the enterocytes was equally severe, depending on the degree of mucosal atrophy. Eosinophil cells were slightly more prevalent in the sprue cases; but this could be due to other features of the tropical environment not necessarily related to sprue.

Numerically, the changes we have recorded in plasma cell population are substantial, both in coeliac disease and chronic sprue, the increase above normal in terms of cross-sectional area being from five to ten-fold. Changes in gross morphology make it difficult to estimate what this means in terms of total plasma cell population. Nevertheless our findings are at variance with those of Crabbé, Douglas, and Hobbs (1970). Using immunochemical techniques they estimated an increase in globulinsecreting plasma cells of the order of only $30 \%$ in untreated coeliac disease, in terms of unit volume. In three cases of chronic sprue the same authors found an actual reduction in the total of these cells below the normal (Douglas, Crabbé, and Hobbs, 1970).

If it is accepted that the prime function of intestinal plasma cells is the production of antibody, the cell 
changes which we have observed suggest that a humoral antibody response is involved in the sprue syndrome, and becomes of increasing importance as the condition becomes chronic.

\section{References}

Chacko, C. J. G., Job, C. K., Johnson, S., and Baker, S. J. (1961). Histopathological changes in the upper jejunum in tropical malabsorption syndrome studied by transoral biopsy. Indian J. Path. Bact., 4, 203-213.

Crabbé, P. A., Douglas, A. P., and Hobbs, J. R. (1970). Immunopathology and coeliac disease. In Coeliac Disease: Proceedings of an International Conference, edited by C. C. Booth and R. H. Dowling, pp. 134-142. Edinburgh, Churchill Livingstone.

Douglas, A. P., Crabbé, P. A., and Hobbs, J. R. (1970). Immunochemical studies of the serum, intestinal secretions and intestinal mucosa in patients with adult celiac disease and other forms of the celiac syndrome. Gastroenterology, 59, 414-425.

England, N. W. J., and O'Brien, W. (1966). Appearances of the jejunal mucosa in acute tropical sprue in Singapore. Gut, 7, 128-139.

Ferguson, A., and Murray, D. (1971). Quantitation of epithelial lymphocytes in human jejunum. Gut, 12, 988-994.

Haeney, M. R., Montgomery, R. D., and Schneider, R. (1974). Sprue in the Middle East: Five case reports. Gut, 15,

Holmes, G. K. T., Asquith, P., Stokes, P. L., and Cooke, W. T. (1973). Cellular infiltrate of jejunal biopsies in adult coeliac disease (ACD) in relation to gluten withdrawal. (Abstr.) Gut., 14, 429.

Montgomery, R. D. Beale, D. J., Sammons, H. G., and Schneider, R. (1973). Postinfective malabsorption: a sprue syndrome. Brit. med. J., 2, 265-268.

Rubin, C. E., and Dobbins, W. O. III, (1965). Peroral biopsy of the small intestine: a review of its diagnostic usefulness. Gastroenterology, 49, 676-697.

Thompson, H. (1973). Personal communication.

Thurlbeck, W. M., Benson, J. A., Jr., and Dudley, H. R., Jr. (1960). Histopathologic changes of sprue and their significance. Amer. J. clin. Path., 34, 108-117.

Whitehead, R. (1971). The interpretation and significance of morphological abnormalities in jejunal biopsies. J. clin. Path., 24, suppl. (Roy. Coll. Path.) 5, 108-124. 